\title{
Enforcing Chinese Antimonopoly Law in the Internet Industry: An Analysis with Special References to Baidu.com*
}

\author{
Zhongmei Wang $^{* *} \&$ Thomas Hoffmann ${ }^{* * *}$
}

Monopolistic mechanisms can be detected in China in many respects through Chinese internet monopolists would outperform their peers in the US or the EU by. The Chinese government endeavors to keep its Internet industry globally competitive and thus authorities involved in antitrust activities tend to tolerate the oligopolistic structure of the market. This is evidenced most obviously in the repression of competitors in certain fields, e.g., 'Baidu,' the 'Chinese Google,' in the field of IT-services - leading to a stricter regime of monopoly control in terms of substantial law. However, in the course of enforcement, various legal and practical challenges impede the efficiency of these measures. This paper analyses existing competition law enforcement and proposes effective application of antitrust law for its enforcement in the Internet industry under present Chinese law.

Keywords: Chinese Antimonopoly Law, Internet Industry, Enforcement, Search Engine, JEL Codes: K21; K42; L41; O3

* This paper is the outcome of the scholarship project funded by Max-Planck Institute of Innovation and Competition in Munich, Germany. The authors would like to thank Professor Dr. Josef Drexl, Dr Peter Picht, and Dr. Gintare Surblyte. Views and errors, if any, are solely the authors' responsibility.

** Professor of Institute of World Economy at Shanghai Academy of Social Sciences. Ph.D. (Xiamen). ORCID: http://orcid.org/0000-0002-8248-4568. The author may be contacted at: zhongmei.wang@outlook.com / Address: Institute of World Economy, Shanghai Academy of Social Sciences, Middle Huaihai Road No. 622-7A, Shanghai 200020 P.R.China.

*** Associate Professor at Tallinn University of Technology School of Law. Ph.D. (Heidelberg). ORCID: http://orcid.org/0000-0003-4761-0722. The author may be contacted at: thomas. hoffmann@ttu.ee / Address: Tallinn Law School, Room SOC-327 Tallinn University of Technology, Ehitajate tee 5, 12616 Tallinn, Estonia. 


\section{INTRODUCTION}

As of June 2014, there were 632 million Internet users in China. It means that the number of users has doubled in less than five years (Figure 1). In the forthcoming decade, China is anticipated to be the fastest growing market for IT-based services in the world, providing opportunities for profit to any company that gains a dominant position. According to the 34th CNNIC Survey of China Internet Development, there were 507 million users of web search engines in June 2014. ${ }^{1}$ Further, the Chinese Internet service market is essentially different from other ones which constitutes a separate geographic features unique to Chinese language and culture.

Taking account of these facts the Chinese government listed the Internet industry among the seven "emerging industries of strategic importance" in 2010. These are entitled to special attention and support from central and local governments in China. ${ }^{2}$ The Internet industry was listed in both the "Decision of the State Council on Speeding up the Cultivation and Development of Emerging Industries of Strategic Importance" and "The Twelfth Five-year Plan for National Economic and Social Development of the People's Republic of China.,"

Unlike the traditional manufacturing industry, the Internet industry is characterized by the network effect, "lock-in" and the "winner-takes-it-all" principle. Thus, monopoly is an object of controversy and ongoing debates across the world. ${ }^{5}$ Monopolistic structures in the Internet industry have developed rapidly since 2010 by the three largest dominant companies - Baidu, Alibaba, and Tencent ("BAT"). They have yet to be seriously threatened or challenged.

Although public enforcement officials have maintained silence and tolerance towards the oligopolistic structure of this market (including industry strategy considerations), private enforcement of Antimonopoly Law in this field has become increasingly active, pacing itself with the rest of the world. Till date, however, there has been highly inefficient application and enforcement of these laws by Chinese authorities who are often not proficient with the specific features of this new industry. There are wide-spread practices of unlawful preferential treatment for local internet enterprises. Also, the rules of competition law have always been a highly contested issue in the field of internet services in China. 
Figure 1: Chinese users of the internet - 2008 to $2014 .{ }^{6}$

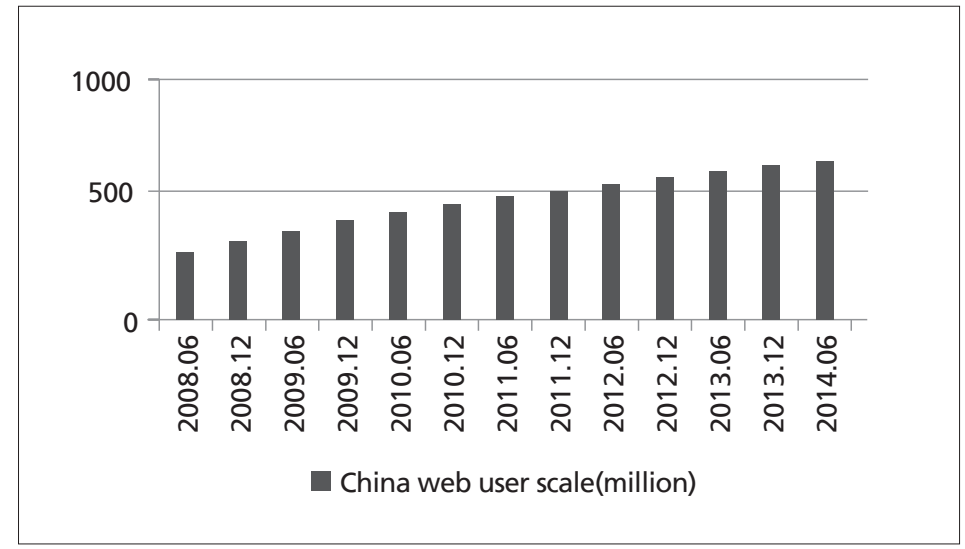

The government has not recognized any necessity for enforcing the Chinese Antimonopoly Law in this industry so far. The 2006-2020 National Information Technology Development Strategy ${ }^{7}$ issued by the State Council, does not deal with competition related issues. In fact, all national strategies and regulatory policies in China are mostly based on the maintenance and development of two key points 'innovation ability' and 'information security.,

Article 1 of the Chinese Antimonopoly Law" defines its goal as "preventing and curtailing monopolistic practices, protecting fair market competition, increasing economic efficiency, safeguarding the interests of consumers as well as society as a whole, and promoting the healthy development of the socialist market economy." Article 27 of the law lists six factors to be taken into account by authorities in the assessment of mergers:

1. market shares and extent of the market power of the parties;

2. existing level of concentration in the market;

3. effect of the proposed merger on potential market entrants or technological development;

4. effect on consumers;

5. effect on national economic development; and

6. any other elements which could affect competition as determined by the Antitrust authority. 
Antimonopoly Law also plays a role within the government's industrial policy guidelines. It will specifically serve for the "development of the socialist market economy." According to Article 27 of the law, the terms 'economic development' and 'national interest' are open to interpretation explicitly favoring domestic industries. Against this background, some believe Chinese Antimonopoly Law is being used to pursue industrial policy objectives. ${ }^{10}$

However, such interpretations would misunderstand the basic principles of Antimonopoly Law, which emphasize exclusively on competition itself and benefits for consumers. ${ }^{11}$ The Chinese mainstream view is not always fully aware that Antimonopoly Law is not designed to directly affect industry performance or to supplement industrial policy. Rather, it seeks to correct problems in both the structure of industries and the conduct of market agents, ensuring efficient economic performance. Hence, even if industrial policy objectives might be considered, Antimonopoly Law's approach to the 'economic development' would be based on "leveling the playing field," neither protecting or supporting domestic industry in general, nor cultivating leading enterprises. ${ }^{12}$

Even though protected as an industrial strategy, the Internet industry is not exempted from Antimonopoly Law. Since measures are taken against firms, not industries, the government's policy consideration may be inappropriate in an individual antitrust investigation. ${ }^{13}$ In principle, industrial policy should be presumed as never directly conflicting with antitrust policy in the sense of competition protection.

However, industrial policies still considerably affect enforcement. In the public domain, Antimonopoly Law has not been fully enforced against the internet monopolies of local companies. Private enforcement is assumed to be rarely successful in China. Until now, only a few plaintiffs have been supported by public and judicial enforcement authorities. Seven years have passed since the implementation of Antimonopoly Law, but legal practices still focus primarily on merger review and pricing - procedures that involve only public enforcement. The US Chamber of Commerce, e.g., explicitly complained that "Antimonopoly Law remedies often appear designed to advance industrial policy and boost national champions."

This research will primarily focus on the practical problems of enforcement of Antimonopoly Law, avoiding emphasis on the value conflicts between industrial 
and competition policies. By analyzing problems found in recent Chinese cases, this paper will tackle key facets such as clear determination of the most efficient enforcement structures and remedy measures for violation of Antimonopoly Law specific to the Internet market.

This paper is composed of seven parts including Introduction and Conclusion. Part two will discuss monopolies in the internet services in China. Part three will investigate the enforcement dilemma, while Part four will examine the threefold public enforcement structure. Part five will analyze the difficulty of private enforcement. Finally, Part six will deal with the issue of open and flexible remedies.

\section{Monopolies in the InTernet Services in China}

Under the tolerance and support by the government, the Internet industry in China has rapidly developed, with its monopolistic structure. On February 17, 2011, China Internet Labs, a private consulting company, published the "Survey on the Internet Monopolistic Situation in China and Research for its Solution." ${ }^{, 15}$ It alleged the existence of an oligopoly since 2010 and reproached the rule of "thewinner-takes-it-all" in segments of the Chinese Internet service market. ${ }^{16}$ Further, the research claimed that even though China's Internet market still provided development opportunities in various branches, entry barriers were artificially high. $^{17}$

The BAT dominates the Chinese Internet industry by extending its businesses to both upstream and downstream markets, including many offline markets such as logistics, tourism, resale and banking. The emergence of mobile Internet services did not successfully challenge the BAT competitively, as the BAT succeeded in gaining control over any promising new entrants by means of mergers, acquisitions or cross-shareholding. According to China News Net, Alibaba spent RMB 30 billion on M\&A in the first half of 2014 alone. ${ }^{18}$

Let's take Baidu for example. Baidu is not only the most popular search engine in China, but also one of the most successful online advertising service providers. Google was likely to hold 55 percent of the global search advertisement revenue in 2015, with Baidu coming in second with an 8.8 percent share of the USD 81.59 billion market. ${ }^{19}$ Remarkably, none of Google's immense revenue comes from 
China, where eMarketer projected a total of USD14.9 billion in search advertising revenue in 2015. Since 2001, Baidu has occupied more than 50 percent of China's search engine market (Figure 2). Now, Baidu is China's leading platform, integrating a variety of diverse products and services.

Table 1: Baidu's leading position in China Market 2014-8 ${ }^{20}$

\begin{tabular}{c|c|c|c}
\hline Rank & Company & Jumped webpage hits percentage & Users coverage \\
\hline 1 & Baidu & $56.33 \%$ & $54.03 \%$ \\
\hline 2 & 360 Search & $29.01 \%$ & $29.24 \%$ \\
\hline 3 & Sougou & $12.75 \%$ & $14.71 \%$ \\
\hline 4 & $21 \mathrm{cn}$ & $0.75 \%$ & $0.45 \%$ \\
\hline 5 & Microsoft Bing & $0.71 \%$ & $0.95 \%$ \\
\hline 6 & Google & $0.27 \%$ & $0.34 \%$ \\
\hline 7 & Others & $0.18 \%$ & $0.29 \%$ \\
\hline
\end{tabular}

Private litigations have been filed in China recently, despite the low success rate; and most judgments are strikingly of poor quality. ${ }^{21}$ According to the official data between August 2008 (when Antimonopoly Law took effect) and the end of 2011, all Chinese Civil Courts have received a total of 61 Antitrust private litigation cases, of which 53 claims were rejected. ${ }^{22}$ Follow-up cases would be a good model for private parties, but in the Chinese Internet market, there are simply too few public enforcements as precedents. ${ }^{23}$ The difficulty may be caused by manifold reasons, but the prominent obstacle for private parties is to discover and prove competition-restrictive practices without public enforcement support. ${ }^{24}$

Although most lawsuits target the three largest companies, Chinese courts are biased in favor of the BAT. In Qihoo v. Tencent, e.g., the Guangdong Provincial High People's Court defined the geographic market from a global, not national, perspective, which meant that in these geographic dimensions, Tencent was not in the position of holding a monopoly, even though it held more than 80 percent of the market. ${ }^{25}$ However, this reluctance to define a 'geographic market' was corrected by the Supreme Court. It still upheld the first instance judgment based on the incompetence of plaintiff to prove the existence of monopolistic position. ${ }^{26}$

In contrast to intensive investigations by Google in the US and in the EU, the 
leading position of Baidu in the search engine market has never been seriously challenged in China. In its 2010 investigation against Google, the European Commission believed that Google had abused its dominant position by: (1) affording preferential placements to the results of its own vertical search services in order to close competing services; (2) increasing the price per click for sponsored links of competing vertical search services; (3) imposing exclusivity obligations on advertising partners; and (4) imposing restrictions on the portability of online advertising campaign data to competing online advertising platforms. ${ }^{27}$ Google, e.g., has contractually restricted advertisers from using data in an interoperable way, discouraging advertisers from running advertising campaigns on competing platforms, known as 'multi-homing. ${ }^{28}$

In March 2011, Microsoft lodged a complaint against Google with the European Commission on interoperability and advertising rather than search manipulation and content piracy. The complaint also raised very important questions concerning the technical development of a sufficiently competitive search engine. ${ }^{29}$ In Microsoft's opinion, Google engaged in a number of exclusionary practices designed to deprive its competitors of the scale they need to effectively compete, even though it brought far smaller benefits to Google itself. $^{30}$ The pool of data stored by Google would enable competitors innovate much more rapidly with the potential of new search-relevant products, which exert a correspondingly higher competitive pressure in the market place. Google has conducted itself in a way that is considerably opaque across online platforms. ${ }^{31}$

The same goes for Baidu. The general search function for searching, e.g., the key word 'music,' the top three results would be Baidu's own products. Another example is that if the key word 'search engine' is searched on Baidu.com, a list of the most recommended search engines would be displayed, but Baidu would be the lead result. It is remarkable that a search engine such as Qihoo 360, which ranks second in China holding over 20 percent market share, would not be included at all in this list. Moreover, Baidu still places its own products in the top of specialized or vertical search results. ${ }^{32}$ The following are noticeable cases involving Baidu in China.

\section{A. The Qihoo 360 Case}

In 2014, Baidu filed a claim for a permanent injunction against Qihoo's crawling 
action and for damages asserted to be Qihoo's profit derived from unfair competition. In fact, it is common practice that Internet search engines use a web crawler (or web robot) to browse the world wide web, typically for the purpose of web indexing. The Robots Exclusion Protocol (hereinafter Robots rules) imposes other web crawlers, the access to the entire website or parts of it. Simply speaking, a web crawler should only be enabled to visit a target website's Robots.txt file. Baidu's Robots.txt contains a white list of allowed web crawlers. It was verified that Qihoo was the only engine provider that was excluded from Baidu's Robots. txt. Although Qihoo has tried to re-initiate negotiations with Baidu, the monopolist has not reacted so far.

Despite Baidu's Robots rules, Qihoo intentionally and consistently crawls Baidu's content-service websites and then provides the crawled data in its own search results. After a few rounds of unproductive talks, Baidu sued Qihoo for unfair competition. On August 7, 2014, the Beijing First Intermediate Court announced its judgment, ruling:

Qihoo's early-stage violation of Baidu's Robots rules, which began in August 2012, constituted unfair competition, whereas Qihoo's later-stage violation of Baidu's Robots rules, which began when both parties signed an Industry Selfdiscipline Convention coordinated by the Internet Association in November 2012, did not constitute an act of unfair competition, because Baidu's refusal to bargain was not consistent with the principle of good faith. Accordingly, the Court allowed Qihoo to continue crawling Baidu's websites. ${ }^{33}$

Baidu places its products on top of general and specific search results, thus increasing their traffic. Most critics have noted that Baidu manipulates its general and paid results in a way that excludes its rivals from top slots in search ranks, depriving them of traffic and, in turn, advertising revenues. ${ }^{34}$ Furthermore, as a powerful web content provider, it also blocked competing search engines from crawling its products.

\section{B. The Renren Case}

Both Google and Baidu hold a dominant position in the general search markets. To make use of these advantages, they post relevant and specialized search results next to general results, confusing users about the background of these 
posts. Through this practice, users of the general search service are easily tempted to click on advertisements. This practice is not compulsive, but of a strongly incenting nature. ${ }^{35}$

As reflected in Renren v. Baidu, ${ }^{36}$ Baidu can demote or even hide some websites' ranking in the general search results to force them to buy the advertisement product 'Baidu Promotion.' In Renren v. Baidu, Renren provided evidence that the traffic to its sites underwent a drop after Baidu blocked it from the general search results. Baidu defended its position stating that Renren had used a robot to automatically make junk posts on various online forums and websites and sent out spam messages (so-called 'junk links') to boost its ranking in Baidu's search results. ${ }^{37}$ Such 'junk links' are explicitly prohibited by Baidu under its public policy (i.e., banning websites with deliberate 'junk links' to artificially promote the website's natural rankings). The final judgment in Renren v. Baidu was that the central interest of consumers is, in a nutshell, accessing correct search results without artificial interference. ${ }^{38}$

Conversely, if there was insufficient evidence to show that Renren has committed fraud or manipulation of that kind, Baidu's practice of blocking or other forms of artificially lowering Renren's ranking in the general search result would be deemed a violation of Antimonopoly Law. In this case, the burden of proof for any justification would be imposed on Baidu if Renren could prove there was a large difference of rankings before and after it decreased its investment in 'Baidu Promotion.'

\section{The Putian Case}

It is exactly Baidu's policy for keyword bidding that has consistently provoked criticisms of exploitation. Even JingDong, one of the most successful online shopping platforms in China, protested against Baidu's practice of charging RMB 5-10 million just to display its company site as a search result for the keyword 'JingDong,' plus the charge of an annual "top ranking fee" by Baidu to stay within the first rank in the search list and avoid imitation and fraud from other paid advertisers. In fact, the CEO of JingDong criticized Baidu rank bidding as 'robbery' in his blog on April 8, 2011 (although it was deleted soon after). ${ }^{40}$

In March 2015, an alliance of private hospitals in Putian city, Fujian province, emphatically protested an advertisement scheme on baidu.com. In an unofficial 
notice leaked on March 25, the Putian Health Industry Association ("PHIA") asked all its members to stop paying Baidu due to its "irrational paid ranking scheme." According to the media, Putian's private hospitals spent RMB 12 billion on Baidu's bidding ranking in 2013, which accounted for 46 percent of Baidu's advertisement income for that year. ${ }^{42}$ Private hospitals have an immense interest in an upper ranking position because China, for many decades, only had public hospitals. Now, private hospitals face a severe challenge competing against public hospitals. The PHIA declared that Baidu made use of its leveraging advantage to charge excessively high advertisement fees. ${ }^{43}$ However, the two parties eventually settled privately. ${ }^{44}$

Exploitive high pricing is one of the abuses of dominance under Article 18 of the Antimonopoly Law. In the Internet industry, the problem exists in the lack of data on the cost of service (i.e., ranking in the keyword search result list). Thus, it is difficult to measure what would be an "unfairly high price." ${ }^{, 45}$ The specific feature of exploitive abuse in the Internet is still connected with the exercise of monopolistic leveraging, which always carries with it compulsion and threats to punish the other side. No private litigation based on this argument has ever achieved the step of assessing what is an "unfairly high price."

By interpreting Article 6 of the Antimonopoly Law appropriately, the manipulation of ranking and discrimination towards certain customers would fall into exploitative abuse and the leverage of monopoly to exclude the competitor in the universal search could be interpreted as an exclusionary abuse. Until now, however, Baidu has never met real challenges based on the Antimonopoly Law. Eventually, Baidu has - as the largest search engine provider in China - occupied almost two thirds of the market and will eventually keep its dominant position for a long time to come. But the reasons for this are not found only in the substantial regulations of the Antimonopoly Law. As the following chapter will elucidate, incompetent and weak enforcement would play a major role.

\section{The Enforcement Dilemma in the Internet SerVICES BRANCH}

In general, private enforcement of the Antimonopoly Law can hardly be achieved 
in China. According to a public media report, 61 Antitrust private claims have been received by different level courts in China, 53 of which have been closed between August 2008 (when the Law took effect) and by the end of 2011, with all plaintiffs losing their lawsuits. ${ }^{47}$ It provides stunning evidence that without support from public enforcement, the private enforcement system is not working well even if it is much more active than public enforcement.

Although industrial policy consideration retards, to some extent, the confused and reluctant enforcement of Antimonopoly Law in the Internet industry is the core reasons for practical difficulties. The Internet is essentially different from traditional industries in terms of its dynamic competition, network and lockingin effects. ${ }^{48}$ Moreover, these differences would impose many new challenges for Antimonopoly Law not just in China, but also in the US and the EU. ${ }^{49}$ Enforcement authorities are also confronted with numerous controversies in this field. ${ }^{50}$ It is not surprising that the inexperienced authorities in China prefer to wait and watch for other countries and the courts to hand down rulings rather than to interfere or sanction themselves without global precedents or supports. There are three enforcement authorities in China, but their jurisdictions are somewhat unclear and unavoidably overlap. At present, all of them are reluctant to initiate an investigation against the BAT. Furthermore, neither government authorities nor the courts have concluded that the Internet should be characterized as a cross market. No effective method has yet to measure its concentration ratio, either. All of these passive factors result in holding little chance for a plaintiff to succeed in litigation against Internet monopolistic companies. ${ }^{51}$

However, the market has been increasingly urging authorities to face circumstances. Since 2011, a rising number of small and medium companies have brought the Internet giants to court, accusing them of cartelization, discrimination, blocking, locking down, bidding manipulations, etc. According to data from the Shanghai Municipal High People's Court, e.g., from August 2008 to August 2013, all Shanghai courts received four private litigations based on the Antimonopoly Law, with two cases involving the Internet industry. ${ }^{52}$ The first antimonopoly case decided by the Supreme Court was Qihoo v. Tencent, ${ }^{53}$ in which both parties were large Internet companies and tried to compete for new business.

In the long term, the enforcement of the Antimonopoly Law in Internet services will inevitably gain ground in China, but, as of today, Chinese authorities are yet 
to prepare for a progressive development. Actually, this is not a uniquely Chinese phenomenon. The implementation of antitrust or competition laws in the Internet industry is a difficult new frontier faced by all major jurisdictions throughout the world. However, China has its own specific dilemmas and difficulties in dealing with this issue.

\section{The Threefold Public Enforcement Structure}

The threefold structure of the Chinese Antimonopoly Law enforcement institutions evoke some confusion among foreigners. Theoretically, there is a clear distribution of competences:

- The Ministry of Commerce ("MOFCOM") is responsible for mergers and monopolistic practices relevant to international trade;

- The National Development and Reform Commission ("NDRC") is responsible for abuse of dominance and anti-competitive agreements directly relevant to pricing issues, but the NDRC focused its investigation mostly on the physical commodity, not on the services; and

- The State Administration for Industry and Commerce ("SAIC") focuses on nonpricing issues. ${ }^{54}$

Figure 2: AML Public Enforcement Structure ${ }^{55}$

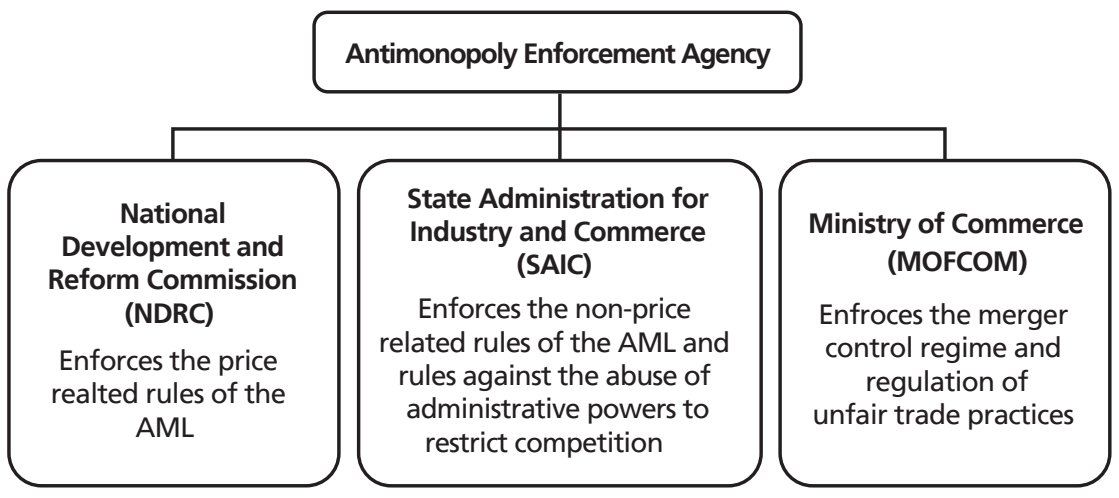

The Chinese AML and its implementing rules do not regulate which agency has 
jurisdiction in the case of a combination of price and non-price related elements within a single case, although in practice the allocation of powers has not been a problem to date. ${ }^{56}$

The agency to investigate within the Internet industry would most likely be the SAIC, as most of the cases involved non-price exclusionary abuses - as shown, e.g., in Tetra Pak. In July 2013, SAIC announced investigations into the alleged abuse of dominant position by Tetra Pak, the Swedish provider of food and beverage packing equipment and related services. Tetra Pak allegedly tied the sale of its packaging materials to its equipment and engaged in discriminatory treatment favoring certain customers. Still, after almost two years, the investigation so far did not result yet in any conclusion. ${ }^{57}$

Compared to the other agencies, SAIC's AML enforcement record to date has been relatively limited, although it was very active at publishing implementing rules and ordinance since 2008. Until the end of 2015, no investigation had been adopted by SAIC or NDRC against any internet service. According to the annual report of SAIC, the industries involved in its antimonopoly investigation covers cigarette, salt, telecommunication, gas and insurance. ${ }^{58}$ As mentioned above, it is mainly because the Internet industry is classified by the government as very important for future national competitiveness. In short, enforcement authorities are generally reluctant to start serious investigations in this field.

In practice, many investigations are impeded by the department of the government regulating the specific industry ${ }^{59}$ before they can take effect. In 2011, e.g., NDRC initiated an investigation into China Unicom and China Telecom over alleged monopolistic price discrimination in the market for broadband Internet service. ${ }^{60}$ It was the first time that monopolistic state-owned enterprises were targeted by antitrust laws. However, the investigation was suspended soon after the two monopolistic companies promised to lower their prices, and no further measures were taken. During the investigation, the industry regulator - the Ministry of Industry and Information Technology ("MIIT") - actually opposed further NDRC antimonopoly investigation. ${ }^{61}$

The suspension might be related to the undisclosed settlement deal between NDRC and MIIT, since these two agencies are, at least in terms of administrative power and clout, equally ranked. NDRC's investigation suffered from various rebounds and necessary rectification under the interference from MIIT, culminating 
in the tolerance of a period of three to five years before China Telecom and China Unicom are able to address the broadband monopoly issue. ${ }^{62}$

On December 29, 2011, MIIT published final rules on competition between providers of Internet information services ("PIIS"), users' rights and protection of online personal data (hereinafter Internet Rules). ${ }^{63}$ The Internet Rules reflect a mixture of antitrust, unfair trade law and consumer protection principles and overlaps to a certain extent with either the AML, the Anti-Unfair Competition Law or the Consumer Protection Law. Article 5 of the Internet Rule prohibits PIIS from:

- Maliciously disturbing competitors' services operating on user devices or disturbing a competitor's IIS-related products from being downloaded, installed, operated, or updated;

- Maliciously making incompatible a competitor's services or relevant products; and maliciously tampering with or deceiving, misleading, or compelling users to tamper with the operating parameters of a competitor's services or relevant products.

This provision is similar to Article 18 of the Chinese AML. According to the above mentioned Internet Rules, MIIT is also competent in investigating any monopoly, unfair competition, and consumer infringement complaints in the IT-based market. The Chinese regulatory structure at present is rather complex, taking into account the frequently overlapping jurisdiction of MOFCOM, NDRC and SAIC. MIIT's involvement as the regulator of IIS increased the regulatory complexity even further. ${ }^{64}$

Noticeably, the Internet Rules have not referred to the Chinese AML or Anti-Unfair Competition Law ("AUCL"), under which SAIC is the major authority responsible for overseeing abuse of dominance and unfair competition conducts. Whether and how far SAIC and MIIT will cooperate in tackling abuse of dominance in the Internet industry will be one of the most interesting developments to be observeed in the near future. 


\section{The Difficulty of Private Enforcement}

Apart from public enforcement, the amount of private claims for damages resulting from anti-competitive conducts is growing quickly in China. According to Article 50 of the Chinese AML, individuals and companies are entitled to bring private actions against undertakings engaged in monopolistic conducts. The first judgment on Article 50 (providing a private claim for damages) was released on October 23, 2009. ${ }^{65}$ The Shanghai First Intermediate People's Court rejected the claim in that the claimant, Beijing Shusheng Electronic Co. Ltd., had failed to provide sufficient evidence that the defendants, Shengda Interactive Entertainment and Shanghai Xuanting Entertainment Information Technology, were dominant. ${ }^{66}$

Most of the private claims were hitherto rejected as the plaintiff could not provide sufficient evidence to define the relevant market and prove a dominant position, or the conducts are seen as being normal business tactics or based within the scope of intellectual property rights. ${ }^{67}$ Although Qihoo tried to bring up expert evidence from international competition economists in Qihoo v. Tencent, the Supreme People's Court accepted it partly and just cited it as auxiliary evidence. ${ }^{68}$

In dismissing Renren v. Baidu in 2009, the Beijing First People's Court issued an obiter dictum regarding dominance in general. ${ }^{69}$ First, the plaintiff must conduct a proper competitive analysis of the relevant market in which the defendant is allegedly dominant. Second, the Chinese AML does not prohibit a dominant market position per se, i.e., the defendant does not have to deny his dominance, whereas the plaintiff not only has the burden of proof to show dominance, but also that the defendant is in abuse of his position. ${ }^{70}$

In 2012, the Supreme People's Court published the "Provisions on the Application of Laws in the Trial of Civil Disputes arising from Monopolistic Practices" (hereinafter SPC Provisions). ${ }^{71}$ The SPC Provisions allow for both stand-alone and follow-on competition claims. Article 2 requires courts to accept stand-alone claims, including those where the alleged monopolistic act is subject to an investigation, but the investigating authority has not confirmed whether an infringement has occurred. The SPC Provisions do not state, however, whether competition authority decisions constitute binding evidence in private actions.

Article 8(1) of the SPC Provisions also clarifies the plaintiff bears the burden of proof for establishing dominant position. Article 9 stipulates that if the defendant 
is a public utility company or an entity with a monopoly privilege granted by law, however, the plaintiff would be exempted from the burden of proof for the dominant position. Besides, Article 10 states that if the defendant has publicly presumed its dominance (such as on his/her own website), these statements would suffice as an evidence of dominance, too.

The SPC Provisions may provide for a broad range of possibilities to a plaintiff. In practice, however, his chances of success are considerably impeded, as the relevant product market always involves two- or multi-sided markets. Monopolistic internet companies in China quickly adapted to the regulation by deleting any statement of dominance from their websites, despite of keeping mere traffic data or user numbers. Anyhow, in Qihoo v. Tencent, this traffic data was not accepted by the courts as an evidence of dominance. ${ }^{72}$

Just as in the US and the EU, another possible approach for a private plaintiff is the follow-on suit. However, the question whether the decision granting public enforcement has binding effect in private enforcement is still pending. In other words, even if there was a public investigation initiated, it would still be hard for a single company to succeed without referring to the decision of public enforcement. Furthermore, most public antimonopoly enforcement procedures lack transparency, and the decisions have seldom been published in details in China. $^{73}$

In particular, the Chinese Civil Procedure Act does not provide an official basis for class action litigation. However, relevant laws do provide for joint actions when one or both parties to a dispute consist of two or more persons. ${ }^{74}$ These joint actions require formal registration with the court. Here, the plaintiffs have to elect a litigation representative, which is completely different from the class action in the US or the EU.

American lawyers have devised various methods to simulate common law class action law suits, especially in cases involving labor contracts or product liability. ${ }^{75}$ In the US, active private antitrust litigation is based on the initiatives of attorneys who target legal triple damages and then the reimbursement of their fees. ${ }^{76}$ Since the success rate of private antimonopoly suits is considerably low, however, the motivation for lawyers to initiate joint actions is weak in China. Besides, China has no facility settings for private litigation like the US (as, e.g., for triple damages or pre-evidence disclosure procedures). 
Furthermore, even a large scale joint action is still very difficult. The All China Lawyers Association ("ACLA") has released guidelines regulating the behavior of lawyers who attempt to organize joint actions. ${ }^{77}$ This guideline requires lawyers to report the case to ACLA and to the Ministry of Justice if joint actions intend to include more than ten plaintiffs. ${ }^{78}$ All these passive factors for private enforcement should be redressed in China's future litigation and judicial practices.

\section{The Open and Flexible Remedies Required}

If assuming that an antitrust claim could be proved against a dominant search engine, the question remains what remedy would be appropriate. In US v. Microsoft, many controversies existed concerning the two main types of antitrust remedies in monopolization cases, namely, conduct remedies and structural remedies. ${ }^{79}$ Conduct remedies are injunctive to a firm's behavior or require to undertake an action it had previously refused. Structural remedies involve dissolution, divorcement and divestiture (e.g., a horizontal structural remedy breaks a firm into components or spills out some competitive business). ${ }^{80}$

In trying to determine the most effective remedy for the abuse of dominance by a search engine, most scholars have focused on the issue of neutrality, which refers largely to conduct requirements. ${ }^{81}$ Even though structural remedies require relatively less regulatory oversight and can be less susceptible to strategic intervention by competitors, they may still fail completely if the required structure does not reflect a correspondingly efficient organization of the industry. ${ }^{82}$ Considering the dynamic competition in the Internet industry ${ }^{83}$ and the current enforcement conditions in China, flexible conduct remedies are preferential to structural ones.

\section{A. Prudentially Applied Structural Remedies}

Considering the cost and inefficiency of conduct remedies and the growing power of large search engines, structural remedies are more likely to be in focus, as demonstrated in a recent investigation against Google. ${ }^{84}$ At present, the European Parliament is preparing a non-binding resolution that proposes to split Google search engine operations in Europe from the rest of its business as one possible 
option to restrict the Internet company's dominance in the search market. ${ }^{85}$

Structural remedies usually involve an obligation to dismantle or separate control over infrastructure, with the effect that a dominant position cannot enable an undertaking from obtaining an unfair competitive advantage downstream or in adjacent markets. ${ }^{86}$ Generally speaking, conduct remedies seek to redress specific forms of conduct, whereas structural remedies are aimed at changing incentives of the dominant firm in the market, ${ }^{87}$ which would hit the basis of its dominance in the long run. In antitrust history, splitting has always been seen as an ultimate measure and thus a very controversial remedy. ${ }^{88}$

The investigation against Google is always compared with the Microsoft case $^{89}$ ten years ago. As Microsoft completely monopolized the IT field of the late 1990s, the US Department of Justice argued that the dominance of Windows could be reduced by directing Microsoft to create software that would run on other platforms just as well as on its own platform, thereby transforming Microsoft's application software into a full-fledged intermediary ware that would allow applications written initially for Windows to run on other operating systems. ${ }^{90}$

In the Microsoft case, the US government failed to show that the proposed (and later abandoned) breakup was an appropriate remedy. The US Department of Justice did not perform an appropriate cost-benefit analysis to show that conduct remedies were insufficient and that a breakup was necessary. ${ }^{91}$ It was argued that - unlike the earlier landmark antitrust cases against steel, oil, tobacco, or aluminum - a successful outcome in the anti-abuse cases against high-technology firms would not simply be an expansion of output and lower prices of a relatively homogeneous commodity, but rather the development of new products to replace or compete with the dominant firm's product or service.

It was also argued that other than in antitrust cases in the 'traditional' industries, a thorough breakup of one of the high-end IT market leaders would eventually hamper the process of innovation in the high-tech industry. ${ }^{93}$ Compared with conduct remedies, structural remedies would be a 'surgical cut' that would impose fundamental impacts on business. It should be thus imposed only if no conduct remedies would serve as efficient deterrents at all. ${ }^{94}$

Contrary to the US or EU, the structural remedy is not a legal remedy for abuse of dominance in China, as it is only available for merger control. ${ }^{95}$ When a concentration raises competition issues, both the parties and MOFCOM may 
propose remedies for reducing its harmful effects and obtaining clearance for the deal. ${ }^{96}$ Those remedies may be structural (e.g., the divestiture of assets) and/ or behavioral (e.g., an agreement to sell below a certain price). ${ }^{97}$ On September 30, 2014, MOFCOM published a Regulation on the Imposition of Restrictive Conditions on Concentrations of Undertakings, ${ }^{98}$ which provided further details on the substantive aspects of remedies.

The question for China is whether a structural remedy as the last resort is indeed necessary for non-merger antimonopoly cases. In other words, it boils down to the question whether - compared to the US and the EU counterparts - the lack of this weapon would make the Antimonopoly Law a "tiger without teeth." Considering that Internet companies are increasingly the platforms with multiple integrated products and services, a structural remedy might be more efficient and effective than a conduct remedy.

However, considering the dynamic competition in the Internet industry, a structural remedy must be prudentially applied, as it would cause unpredictable and potentially severe impacts on the business. Furthermore, the suggested splitting up of Google by separating its search business from its advertising business would leave the company without any resort for subsidizing its free search service. ${ }^{99}$ The interest of the consumer should be comprehensively taken into account. Not only is his/her interest the economically advantageous (i.e. cheap) access to Internet services provided by these companies, but also the availability of technically precise, advanced and integrated services. ${ }^{100}$

Less intrusive remedies - such as interconnection requirements, labeling and publication of algorithms - are less risky in industries with rapidly changing technology. However, technically, such remedies generally require continuing supervision by the authorities and are thus often seen as being more problematic than the "once and for all" imposition of structural relief. In EC v. Microsoft in 2004, e.g., the European Commission adopted the decisions: (1) to establish a monitoring mechanism and appoint a monitoring trustee paid for by Microsoft (under Article 7(1) of Reuglation 1/2003); and (2) to provide for periodic penalty payments of up to Euro 2 million per day should Microsoft fail to comply with the terms of the Commission's infringement decision (under Article 24(1) of Reuglation 1/2003). ${ }^{101}$

Naturally, competitors criticized ${ }^{102}$ the Google settlement proposal to the 
European Commission as a weak conduct remedy that would not remove the restrictive effects of abuse. However, the purpose of Antimonopoly Law is not to destroy a powerful company but to comprehensively protect consumers' and competitors' interests. Against this background, it would also be advisable in the case of Baidu to adopt new types of conduct remedies rather than focusing excessively on structural remedies.

\section{B. More Flexible Conduct Remedies}

In accordance with Articles 46, 47 and 49 of the Chinese AML, where an undertaking enters into a prohibited monopoly agreement or abuses its dominant position, the relevant agency may order it to cease and desist, confiscate any illegal earnings and impose a fine of 1 to 10 per cent (depending on the nature, degree and duration of the violation) of the undertaking's turnover in the preceding year. It is unclear whether this turnover-based fine relates to the worldwide turnover, turnover in China, or turnover in the relevant market. ${ }^{103}$

The lack of publication requirements for decisions adopted by NDRC or SAIC under the Antimonopoly Law does not allow for a comprehensive review of the authorities' sanctioning practices. ${ }^{104}$ Based on the few announcements that have been published, a total of USD 97.5 million in fines ${ }^{105}$ and confiscated profits have been imposed since August 2008, although the statutory basis for the fines is not always clear; some of these sanctions may have been imposed under the Price Law. $^{106}$

Article 50 of the Antimonopoly Law provides that when an undertaking causes other parties to suffer a loss as a result of abusing its dominant position or entering into a monopoly agreement, it may face civil liability. The civil courts' jurisdiction does not appear to be limited to the award of damages. Consistent with general principles of civil and contractual law, the courts may also declare that the Antimonopoly Law to be invalid and may grant injunctions and cease-and-desist orders. $^{107}$

If taking into account only Chapter VII of the Chinese AML, the available antimonopoly remedy measures are very simple and conservative, and this is reflected in the jurisprudence of administrative law and civil law. It, does not reflect the purpose of antitrust law. Considering the specific requirements for restoring or keeping dynamic competition in Internet antitrust cases, the 
introduction of some new and flexible remedies into the Chinese AML seems necessary and urgent. The most important of those supplemental remedy measures are disclosure and access remedies.

\section{Specific Proposals}

Regarding the violations based on the structure of search bias, ${ }^{108}$ e.g., an ideal conduct remedy would compel the search engine to change the ranking on its own and its competitor's products, which would involve a complex change in the search algorithm. Nevertheless, important technical difficulties arise in terms of supervision. In the Microsoft case, a technical committee was set up to monitor Microsoft's compliance with the judgment, which was confronted with much more criticism. ${ }^{109}$ The monitoring of a search engine would be even more difficult because each search algorithm would contain generally the same source code. Here, the resources required to isolate newly introduced, bias-inducing codes could be substantially reduced by ignoring the code that remains unchanged from prior iterations. ${ }^{110}$

Even if an outside technical expertise committee could monitor a decree with the required accuracy, it would be very difficult for a judge or a government officer to issue and monitor such a decree. Furthermore, search rankings could repeatedly change in the course of an enforcement proceeding, making an accurate and speedy adjudication of all but the most severe instances of search bias impractical or impossible, as subsequent changes turn alleged harms irrelevant. ${ }^{11}$

Moffat maintained that the free market and dynamic competition would sooner or later discipline the search engine market. ${ }^{112}$ If a search engine could not always provide exact information for the needs of users, it would gradually lose users' trust and, in turn, lose profits on the other side of the market. However, the key argument against this opinion is that it is difficult for general users to discover search-engine misconduct. ${ }^{113}$ Until now, the most practical remedy at hand has therefore been to force the disclosure of search bias. The US FTC issued a letter to various search engines regarding paid ranking and paid inclusion practices. The guidelines contained in the letter advised search engines to ensure that:

(1) any paid ranking search results are distinguished from non-paid results with clear and conspicuous disclosures; (2) the use of paid inclusion is clearly and conspicuously explained and disclosed; and (3) no affirmative statement is 
made that might mislead consumers as to the basis on which a search result is generated. $^{114}$

After the 2002 Search Engine Letter was issued, most US search engines embraced the letter's guidance and distinguished any paid search results from other advertising ones on their websites. Nevertheless, FTC observed a decline in compliance with the letter's guidance. In 2013, FTC issued a new letter, which emphasized that clarity and prominence of advertising disclosures are of key importance. ${ }^{115}$

These basic presumptions underline that conduct remedies should take into account the fact that consumers ordinarily expect natural search results to be included and ranked based on relevance to a search query, not based on payment from a third party. ${ }^{116}$ Therefore, search engines may use a noticeable and understandable method to distinguish advertising results. [Emphasis added] The standard for "noticeable and understandable" should be referd to a nonprofessional consumer.

In the Baidu case, there is no clear differentiation in the search result list as to whether the listed was paid for by a client or naturally calculated. As users click more often on those links listed on the top, after a period of time, the (toplisted) paid search results would become the top ranked even in the natural search list. According to Baidu's algorithm, its search results are based on the number of clicks (instead on relevance), which would lead ordinary users to mistake the top one as the most relevant or best one. ${ }^{117}$ The central question remains on the isolation of the bias-inducing code from the construction of a search algorithm. At present, largely due to the failure of enforcement actions against Baidu, the mixture of bias results and natural results is becoming even more indistinguishable. ${ }^{118}$

In China, an essential first step should coerce the Internet industry for more disclosure. As for the search engines, any paid service should be clearly labeled as being paid for, and biased results should be isolated from the natural results in the search algorithm. Considering the incompetence of enforcement authorities in monitoring the compliance of search engines, an open dialogue with all interested stakeholders, including downstream websites, large and small search engines, computer science experts, and consumers, would be the most efficient path to a sustainable solution. ${ }^{119}$ 
Moreover, on a global scale, remedies increasingly focus on access to network industries and platform technologies. ${ }^{120}$ In an economy increasingly dominated by information and information technology, access is often dependent on interoperability. ${ }^{121}$ It is thus not surprising that antitrust remedies have increasingly focused on the disclosure of competitively necessary information and the protection of competitively sensitive information obtained from actual or potential competitors. ${ }^{122}$ The access remedy would thus be one of the most important types of remedies for Internet antitrust legislation.

Typically, access remedies involve either granting direct/indirect competitors access to an essential technology or infrastructure, or ensuring the interoperability of access by a seeker to products or services with the key services, products and platforms of the defendant undertaking the search. ${ }^{123}$ Assess remedy is a preferred and recommended category of remedy especially suitable for the Internet or hightech antitrust. ${ }^{124}$ Assess remedy is also very new to Chinese enforcement, as it has not been included in Article 47 of the Chinese AML, but it has also been adopted in practice through settlement proposals or promises from companies being investigated. $^{125}$

Let's take into account that such access remedies may need to be prescribed in great detail; their impacts might play a fundamental role in shaping affected industry's structure; or the defendant undertaking might need restructuring of its corporate configuration to be able to fully satisfy access requests (as defined). In these cases, it is clear that such remedies will go well beyond what has been traditionally considered to be a behavioral remedy and can thus be considered quasi-structural. $^{126}$

Eventually, the authors would advocate, in principle, to prefer the application of conduct remedies, mainly for three reasons. First, conduct remedies avoid the excessive application of behavioral remedies and limit their use to circumstances in which they are necessary to address monopoly concerns. Second, they can help ensure that the application of such remedies does not unduly negate the procompetitive impact of the proposed transaction. Third, based on the last two principles, conduct remedies are structurally more 'open' and 'flexible' so that they can thus be tailored for case-specific needs. 


\section{Conclusion}

Since the Microsoft case, ${ }^{127}$ the controversy of the appropriateness and efficiency of antitrust measures in the IT industry has steadily increased. Reasons for the inefficiency are manifold. In part, 'efficiency' has simply decreased by structural arrears; D. Koppel states on that point that: "If the 'monopoly' is likely to have a shorter lifespan than the time it takes to try an antitrust case, then the rationale for government action is considerably weaker; indeed, it disappears entirely." ${ }^{128}$

Considering dynamic competition in the Internet industry, any form of antitrust enforcement requires a sound cost-effort-analysis a priori. Kopel even argued:

The history of 110 years of Sherman Act prosecutions shows that waiting for principled, consistent, pro-competitive enforcement of the Act is like waiting for Godot. It theoretically could come. However, there is little reason to believe it ever will; even if it did, there is no reason to believe it would stay for long. ${ }^{129}$

However, in many ways, the situation in China is essentially different from that in the US. Eight years have passed since the implementation of the Chinese AML has not sufficed in the generation of full attention to the specific mechanisms of these undertakings. The risks of antimonopoly have seldom been included in the consideration of the companies when adopting a business tactic, especially in the fast-growing industries. The industrial policy has always dominated the business environment in China. Compared with the competition policy, however, it appears more narrow, arbitrary, unstable and unpredictable. Especially in the Internet industry, under the umbrella of "industry of strategic importance," a monopolistic market structure emerged very quickly.

Since 2010 - when the Chinese Internet market entered a state of oligopoly-, the "winner-takes-it-all" model has become a high barrier for new entrants. Mostly, due to a lack of experience and motives, the relevant authorities are reluctant to enforce antimonopoly law in the Internet service market. However, theoretically, although tactics and strategies might vary considerably, business behaviors should be kept under control by antitrust regulations and be sanctioned if harm to either consumers or competition could be proved to exist in the upstream, downstream and parallel markets.

In fact, the Internet market itself pushed the authorities to the battlefront of 
antimonopoly. China is confronted with competition and antimonopoly issues as similarly found in all other main jurisdictions in the world. The private enforcement in this field has been decisively more active in the last five years. Especially since Qihoo v. Tencent, the enforcement of antimonopoly law in Internet services seems to begin to emerge, although it seems that enforcement authorities are not yet ready to be confronted with this task.

Considering the confusion and difficulty reflected in both the judiciary and legislation in China, there are at least three key facets, namely: (1) the need to clarify and somehow form the threefold public enforcement structure; (2) the need to encourage and facilitate the private enforcement, and; (3) the need to implement a system of flexible and comprehensive remedies.

The overlapping competence between the three enforcement authorities in China has contributed to some extent to the reluctant and silent public enforcement of the AML in the Internet industry, which is aggravated by the industrial policy interference, especially for NDRC. Without any support from the public enforcement, private enforcement is doomed to fail in general for the time being. Moreover, the AML remedies framework also seems outdated and not fit for the dynamic features of internet.

If the Chinese government is willing to make (and partially to keep) its Internet industry globally competitive, it should adopt more difficult antimonopoly enforcement. Nevertheless, in China where the dominance of some largest companies leads to a strikingly obvious repression of competitors just as we suggested, a stricter regime of antimonopoly control would finally assist companies to generate truly global competitiveness, not simply national monopolies nourished by protectionism.

\section{REFERENCES}

1. The 34th CNNIC Survey of China Internet Development (July 2014) <available only in Chinese>, available at http://www.cnnic.cn/hlwfzyj/hlwxzbg/hlwtjbg/201407/P020140721 507223212132.pdf (last visited on Aug. 6, 2016).

2. Decision of the State Council on Accelerating the Fostering and Development of Strategic Emerging Industries [国务院关于加快培育和发展战略性新兴产业的决定], NDRC (2010) No. 32 <available only in Chinese>, Oct. 18, 2010, available at http://www.gov.cn/zwgk/2010- 
10/18/content_1724848.htm (last visited on Aug. 6, 2016).

3. Id.

4. Notice of the Plan for National Strategic Emerging Industry Development [国家战略性 新兴产 业发展规划的通知], NDRC (2012) No. 28 <available only in Chinese>, July 9, 2012 available at http://www.gov.cn/zwgk/2012-07/20/content_2187770.htm (last visited on Aug. 6, 2016).

5. See, e.g., D. Kopel, Antitrust after Microsoft: The Obsolescence of Antitrust in the Digital Era, The Heartland Institute, 2001; OECD, Application of Competition Policy to High Tech Markets 9, OCDE/GD (97)44 (1996), available at http:/www.oecd.org/competition/ abuse/1920091.pdf; P. Barbur \& J. Clarke, Antitrust Standing and the New Economy, NAT'L L. J. Nov. 28, 2011, available at https:/www.cravath.com/files/Uploads/Documents/ Publications/3320222_1.pdf (all last visited on Aug. 6, 2016).

6. CNNIC Survey of China Internet Development <available only in Chinese>, available at https://www.cnnic.net.cn/hlwfzyj/hlwxzbg/hlwtjbg (last visited on Aug. 6, 2016).

7. National information development strategy 2006-2020 [2006-2020 年国家信息化发展战略], $<$ available only Chinese>, available at http://www.china.com.cn/chinese/PI-c/1203246.htm (last visited on Aug. 6, 2016).

8. Zhong Ban Fa (2006) No. 11 Notice. See Some Issues Requiring Attention ch. II(2)

9. Chinese Antimonopoly Law [中华人民共和国反垄断法], promulgated on August 30, 2007 by the twenty-ninth meeting of the Standing Committee of the Tenth National People's Congress <available only in Chinese>, available at http://www.gov.cn/flfg/2007-08/30/content_732591. htm (last visited on Aug. 6, 2016).

10. M. Mariniello, The Dragon Awakes: Is Chinese Competition Policy A Cause for Concern?, Bruegel Pol'y Contribution 5 (2013).

11. It still involves the unsettled debate between Chicago School who insist on consumers' welfare and Harvard School who value the maintenance of competition. Both schools exclude and object to other criterions beyond consumers and competition.

12. Zhongmei Wang, How to Redress the Deficiencies of Antimonopoly Law, 10 S.W. U. PoL. SCI. \& L. Rev. 63-7 (2008).

13. G. Miller, The Impacts of Antitrust Enforcement on Industry Performance 43 (1993).

14. US Chamber of Commerce, Competition Interests in China's Competition Law Enforcement: China's Anti-Monopoly Law Application and the Role of Industrial Policy (2013), at ii, available at https://www.uschamber.com/sites/default/files/Antimonopoly Law_final_090814_final_locked.pdf(last visited on Aug. 6, 2016).

15. After 2015, there is no update on the website of China Internet Lab, with many resources deleted. Therefore, the report could only be found on the third party's website, available at http://wenku.baidu.com/link?url=Djt_NGq6OhdPZxmoAqAEjMje2pMGuGq9qbsM7ZgG ECvOjRa1Ky6aecNJfW03uaFjO18oJQUcfCHPu1DI10zlC1axYjqkEUedukBpdEe-pzu. For details on the report summary, see ScI. TIMES, Mar. 26, 2011, at B2, available at http://news. sciencenet.cn/sbhtmlnews/2011/3/242747.html?id=242747 (last visited on Aug. 6, 2016). 
16. Id.

17. For the second article of Report Summary, see ScI. Times, Apr. 6, 2011, at B2, available at http://news.sciencenet.cn/sbhtmlnews/2011/4/243080.html?id=243080 (last visited on Aug. 6, 2016).

18. See, BAT Crazy M\&A Becomes the Industry Trend, PeopleNet, July 1, 2014, available at http://media.people.com.cn/n/2014/0701/c14677-25221678.html (last visited on Aug. 7, 2016).

19. Google Will Take 55\% of Search Ad Dollars Globally in 2015, available at http://www. emarketer.com/Article/Google-Will-Take-55-of-Search-Ad-Dollars-Globally-2015/ 1012294 (last visited on Aug. 7, 2016).

20. CNZZ Search Engine Analysis Report <available only in Chinese>, available at http:// engine.data.cnzz.com (last visited on Aug. 7, 2016).

21. Song Xue, Oligopoly Appears in Internet, and Antitrust Investigation Fronted with Difficulty of Proof [互联网多领域现寡头垄断 反垄断调查遭遇举证难] < available only in Chinese>, Guangzhou Daily, Feb. 24, 2011, available at http://www.chinacourt.org/article/ detail/2011/ 02/id/441808.shtml (last visited on Aug. 7, 2016).

22. Weichen Sun, Is Possible for the Ordinary People to Win A Monopolistic Enterprise? <available only in Chinese>, 20 China ECon. WeEkly, May 21, 2012, available at http:// paper.people.com.cn/zgjjzk/html/2012-05/21/node_1422.htm?div=-1 (last visited on Aug. 7, 2016).

23. Jian Li, Dilemma of Civil Antimonopoly Litigation and the Development of Antimonopoly Regulation, 5 Leg. Res. 72 (2011).

24. See, e.g., Renren v. Baidu, Beijing 1st Intermediate People's Court (2009) Yi Zhong Min Chu Zi No. 845 verdict.

25. Qihoo v. Tencent, Guangdong People's High Court (2011) Min San Chu Zi No.2 verdict.

26. Qihoo v. Tencent, Supreme People's Court (2013) Min San Zhong Zi No. 4 verdict [奇虎公 司与腾讯公司垄断纠纷上诉案判决书] < available only in Chinese>, available at http://www. court.gov.cn/zixun-xiangqing-6765.html (last visited on Aug. 7, 2016).

27. ICOMP, Google under Antitrust Microscope, Oct. 20, 2011, at 4 \& 14, available at http:// www.i-comp.org/wp-content/uploads/2013/07/1213_Google_antitrust_lores_screen.pdf (last visited on Aug. 7, 2016).

28. Id. at 5 .

29. Id. at 14 .

30. Id.

31. Id. at 29.

32. See Interactive Encyclopedia v. Baidu, Beijing 1st Intermediate People's Court (2011) Yi Zhong Min Chu Zi No. 10190 verdict.

33. Beijing 1st Intermediate People's Court (2014) Yi Min Zhong Zi No. 08599 verdict.

34. Supra notes $24 \& 33$. 
35. M. Ammori \& L. Pelican, Competitors' Proposed Remedies for Search Bias: Search "Neutrality" and Other Proposals, 15 J. INTERNET L. 15-6 (2012), available at https://ammori.files.wordpress. com/2012/05/jil_ammori-ma-conference-version-formatted.pdf (last visited on Aug. 10, 2016).

36. Supra note 24.

37. Id.

38. A. Zhang, Using A Sledgehammer to Crack A Nut: Why China's Anti-Monopoly Law was Inappropriate for Renren v. Baidu, 7 Comp. Pol. InTL. 289-98 (2010).

39. Zongchuan Wan, On the Amendment of Evidence Rules in Antimonopoly Civil Action, 30 HeBEI L. Sci. 93-5 (2012).

40. See Baidu: The Evil based on Monopoly [百度, 垄断下的恶] <available only Chinese>, Aug. 18, 2011, available at http://news.cntv.cn/special/uncommon/11/0818 (last visited on Aug. 9, 2016).

41. See, e.g., Putian hospitals and Baidu broke up, hurting each other [莆田系医院和百度彻底 闹班了, 杀敌一万自损三千] Netease, Apr. 5, 2015, available at http://news.163.com/15/ 0405/11/AMEFF40A00014U9R.html (last visited on Aug. 10, 2016).

42. Id.

43. Weijue Yan, Hospital Coalition Calls Out Baidu, China Daily, Mar. 31, 2015, available at http://www.chinadaily.com.cn/m/fujian/2015-03/31/content_19964095.htm (last visited on Aug. 10, 2016).

44. Afterwards, in May 2016, a college student died in one of the private hospital ranked high in Baidu ranking list. Most criticism goes for PHIA and the business ethics of Baidu. However, no public comments ever focused on the abuse of dominance by Baidu in misleading consumers and manipulating the downstream competition. See Shichuan Wang, Commentary: Death of college student raises questions on Baidu's ethics, People's Daily, May 2, 2016, available at http://en.people.cn/n3/2016/0502/c90000-9052118.html (last visited on Aug. 10, 2016).

45. For details on the interpretation of "unfairly High Price" in Article 18 of Antimonopoly Law, see D. Evans et al., Accessing Unfair Pricing under China's Antimonopoly Law for Innovation-intensive Industries, Coase-Sandor Institute for Law and Economics Working Paper No. 678 (2014), available at http://chicagounbound.uchicago.edu/cgi/viewcontent. cgi?article=1668\&context=law_and_economics (last visited on Aug. 9, 2016).

46. Regarding public enforcement, Article 11 of the Anti-Price Monopoly Regulations provides that NDRC could judge and decide penalties for such an excessive pricing. See id. at 47-9.

47. Weichen Sun, Is Possible for the Ordinary People to Win A Monopolistic Enterprise? [老百 姓告“垄断企业”能赢吗? ] <available only in Chinese>, 20 CHINA ECON. WeEKLY (May 2012), available at http://finance.people.com.cn/GB/18008670.html (last visited on Aug. 9, 2016).

48. G. Smith, Internet Law and Regulation 1-3 (3d ed. 2002).

49. Jung Wook Cho, Innovation and Competition in the Digital Network Economy 21-40 
(2007).

50. Haipeng Shao, Assessment of the Gains and Loss of Internet Antitrust through $3 Q$ case, Oct. 20, 2014, available at http://finance.sina.com.cn/roll/20141020/020420581025.shtml (last visited on Aug. 9, 2016).

51. Xue Song, Oligopoly Appears in Internet, and Antitrust Investigation Fronted with Difficulty of Proof, Guangzhou Daily, Feb. 24, 2011, available at http://www.chinacourt.org/article/ detail/2011/02/id/441808.shtml (last visited on Aug. 9, 2016).

52. Kailin Wu, The Introduction of Antimonopoly Lawsuits Judged by Shanghai Courts since Antimonopoly Law Become Effective [《反垄断法》实施以来上海法院审理垄断纠纷案件的基本 情况] <available only in Chinese>, Aug. 1, 2013, available at http://www.hshfy.sh.cn/css/ webpub/upload/201308021018332523.doc (last visited on Aug. 9, 2016).

53. Supra note 26.

54. AML art. 10; Art. 6 and 7 of Anti Unfair Competition Law arts. $6 \&$ 7; and Price Law art. 5.

55. This schematic framework drawn by the authors based on AML, Price Law, Anti Unfair Competition Law and relevant regulations.

56. In fact, the separation of competences for pricing and non-pricing issues appears somewhat artificial, since antitrust infringements usually have both effects on price and other than price.

57. See Annual Report of 2014 on Antimonopoly and Anti Unfair Competition Enforcement by SAIC [高擎利剑 忠诚履职 2014 年工商机关反垄断与反不正当竞争执法工作综述] <available only in Chinese>, Jan. 28, 2015, available at http://www.saic.gov.cn/jgzf/fldyfbzljz/201501/ t20150128_151703.html (last visited on Aug. 9, 2016).

58. Id.

59. Xiaoye Wang, Some Issues about China Antimonopoly Enforcement Authorities, 1 Dong Yue Tribune 39-41 (2007).

60. Jiang Li, Behind the Antimonopoly Investigation against China Telecom and China Unicom, 14 Technology \& Enterprises 1 (2011). See also Chen Chen, Antitrust investigation to telecommunications industry is not a "war of gods," People's Daily, Nov. 14, 2011.

61. Id.

62. Lang Lang, NDRC Says that the Antimonopoly Investigation into Broadband Has Not Been Closed, 21 Century Economic Report [发改委宽带反垄断调查尚未结案] <available only in Chinese>, JD.Com, Dec. 10, 2012, available at http://business.sohu.com/20121212/ n360161518.shtml (last visited on Aug. 9, 2016).

63. Several Rules on Maintaining the Internet Information Service Market Order, MIIT Decree No. 20, <available only in Chinese>, Mar. 15, 2012, available at http://baike.baidu.com/ link?url=Gwfrw40mHBOSPQLS5evCdRq5KsOc1J3cvt04tEmIooRzPp3ZfpM0OkOycFPwIf7UKzB0G23PlcofrHmtIQSaq\#1 (last visited on Aug. 9, 2016).

64. Supra note 60.

65. Yunlong Hou \& Lihua Wu, Hard for Private Antimonopoly Litigation against Giant 
Companies [状告大企业垄断难有结果 反垄断任重道远], ECONOMIC INFORMATION DAILY, Oct. 22, 2009, available at http://news.xinhuanet.com/fortune/2009-10/22/content_12293731. $\mathrm{htm}$ (last visited on Aug. 11, 2016).

66. Shusheng IT Ltd. v. Shanghai Shengda Network Ltd., Shanghai People's 1st Middle Court (2009) Hu Yi Zhong Min Wu (Zhi) Chu Zi No. 113 verdict.

67. Penchen Zhen, Difficulty of Private Enforcement of AML and Its Resolution: A Prospective Discussion, 3 JuRISTS 99-100 (2010).

68. Hanhong Wu, Wei Zhou \& Xiaoya Zhang, Past, Now and Future of China Competition Policy, 11 Fin. \& Trade Econ. 109-10 (2008).

69. Supra note 24.

70. Id.

71. Provisions of the Supreme People's Court on Several Issues concerning the application of law in the trial of civil cases of civil disputes caused by monopolistic conduct 最高人 民法院关于审理因垄断行为引发的民事纠纷案件应用法律若干问题的规 < available only in Chinese>, July 18, 2012, available at http://www.china.com.cn/guoqing/zwxx/2012-07/18/ content_25940619.htm (last visited on Aug. 11, 2016).

72. Supra note 25.

73. Yanfei Shen, Chinese Style Antimonopoly Storms, 17 Fangyuang 55-6 (2014).

74. Chinese Civil Procedure Act, arts. 53 \& 55.

75. ACLA Guiding Opinions of the All China Lawyers Association on the Handling of Class Action Cases by Lawyers, Mar. 30, 2006, available at http://www.lawyers.com.cn/info/1 lb bfabc2ecafed984ec364d6e6b8877 (last visited on Aug. 11, 2016).

76. Id.

77. Guiding Opinions of the All China Lawyers Association of the All China Lawyers Association Regarding Lawyers Handling Cases of a Mass Nature (CECC Full Translation), Mar. 20, 2000, Congressional-Executive Commission on China, available at http://www. cecc.gov/resources/legal-provisions/guiding-opinion-of-the-all-china-lawyers-associationregarding-lawyers (last visited on Aug. 11, 2016).

78. Supra note 75.

79. R. Gilbert \& M. Katz, An Economic Guide to US v. Microsoft, 15 J. Econ. PersPective 3941 (2001).

80. Id.

81. Supra note 35, at 10.

82. Supra note 79 , at 40.

83. A. Langford, Monopoly: Does Search Bias Warrant Antitrust or Regulatory Intervention?, 88 IND. L. J. 1583-4 (2013).

84. N. Economides \& I. Lianos, A Critical Appraisal of Remedies in the EU Microsoft Cases, 2 Colum. Bus. L. Rev. 398-404 (2009).

85. A. Oreskovic, J. Floretti \& A. Macdonald, European Parliament may Propose Google 
Break-up in Draft Resolution, Reuters, Nov. 21, 2014, available at http://www.reuters.com/ article/2014/11/21/us-google-antitrust-idUSKCN0J525V20141121 (last visited on Aug. 11, 2016).

86. Supra note 27.

87. F. Maier-Rigaud, P. Hellstrom \& F. Wenzel Bulst, Remedies in European Antimonopoly Law, 76 Antimonopoly L. J. 47 (2009).

88. Supra note 83, at 1584.

89. United States v. Microsoft Corporation, 253 F.3d 34 (D.C. Cir. 2001).

90. K. Elzinga, D. Evans, \& A. Nichols, US v. Microsoft Corp.: Remedy or Malady?, in Microsoft, Antitrust and The New Economy: Selected Essays 138 (D. Evans eds., 2002).

91. Id.

92. R. Crandall \& C. Jackson, Antitrust in High-Tech Industries 1 (2010), available at http:// techpolicyinstitute.org/files/crandalljackson\%20antitrust_in_high_tech3.pdf (last visited on Aug. 11, 2016).

93. M. Radke, Law and economics of Microsoft vs. US Department of Justice: new paradigm for antitrust in network markets or inefficient lock-in of antitrust policy?, Stuttgart-Hohenheim No. 16/2001 (2001), at 42, available at http://opus.uni-hohenheim.de/volltexte/2010/457/ pdf/16_2001.pdf (last visited on Aug. 11, 2016).

94. Supra note 79 , at $40-3$.

95. AML arts. 46-48.

96. Id. arts. $28 \& 29$.

97. Id. art. 48.

98. Micheal Gu, MOFCOM Updated Rules on Merger Control Filing, China Law Vision, June 20, 2014, available at $\mathrm{http}: / / \mathrm{www} . c h i n a l a w v i s i o n . c o m / 2014 / 06 /$ articles/merger-and-acquisition/ mofcom-updated-rules-on-merger-control-filing (last visited on Aug. 11, 2016).

99. G. Manne \& J. Wright, Google and the Limits of Antitrust: The Case against the Antitrust Case against Google, Lewis \& Clark Law School Legal Research Paper Series No. 201019, at 20-2, available at http://www.law.gmu.edu/assets/files/publications/working papers/1025GoogleandtheLimits.pdf (last visited on Aug. 11, 2016).

100. Id. at 70-2.

101. European Commission v. Microsoft, No. COMP/C-3/37.792 (2004), available at http:// ec.europa.eu/competition/antitrust/cases/dec_docs/37792/37792_4177_1.pdf. See also European Commission press release IP/06/979, Brussels, July 12, 2006, available at http:// europa.eu/rapid/press-release_IP-06-979_en.htm (all last visited on Aug. 11, 2016).

102. C. Miller \& M. Scott, Google Settles Its European Antitrust Case; Critics Remain, N. Y. Times, Feb. 5 2014, available at http://www.nytimes.com/2014/02/06/technology/googlereaches-tentative-antitrust-settlement-with-european-union.html (last visited on Aug. 11, 2016).

103. AML arts. $46 \& 47$. 
104. Article 44 of AML just stipulates that the enforcement could publish its negative decision. However, Article 30 requires MOFOCOM should publish its decision to block a M\&A or impose some conditions.

105. See NDRC decision on Qualcomm abuse of dominance on Feb. 10, 2015. See Antitrust in China: NDRC v. Qualcomm - One All, Feb. 12, 2015, available at http://www.allenovery. com/publications/en-gb/Pages/Antitrust-in-China-NDRC-v--Qualcomm-\%E2\%80\%93One-All.aspx (last visited on Aug. 11, 2016).

106. Price Law (1998), available at http://www.gov.cn/banshi/2005-09/12/content_69757.htm (last visited on Aug. 11, 2016).

107. Supreme People's Court Draft Regulation on Issues concerning the Application of the Law in Civil Disputes Involving Monopolistic Conduct of 25 April 2011, arts. 17 \& 18.

108. For a brief guide to search bias, see F. Pasquale, Paradoxes of Digital Antitrust: Why the FTC Failed to Explain Its Inaction on Search Bias, Harv. J. L. \& Tесн. Occasional Paper Series 3-5 (July 2013), available at http://jolt.law.harvard.edu/antitrust/articles/Pasquale. pdf (last visited on Aug. 11, 2016).

109. Supra note 35 , at 15-7.

110. Supra note 83 , at 1584 .

111. Id. at 1585 .

112. V. Moffat, Regulating Search, 22 HaRv. J. L. \& TЕСH. 490 (2009), available at http://jolt. law.harvard.edu/articles/pdf/v22/22HarvJLTech475.pdf (last visited on Aug. 11, 2016).

113. The Power of Google: Serving Consumers or Threatening Competition? Hearing before the Subcommittee of Antitrust, Competition Polity and Consumer Rights of the Committee on the Judiciary, US Senate, at 42-4, Sept. 21, 2011, available at http://www.judiciary.senate. gov/meetings/the-power-of-google-serving-consumers-or-threatening-competition (last visited on Aug. 11, 2016).

114. Commercial Alert Letter from Heather Hippsley, Acting Assoc. Dir., Div of Adver. Practices, Fed. Trade Comm'n, to Gary Ruskin, Executive Director, Commercial Alert June 27, 2002, available at https://www.ftc.gov/sites/default/files/documents/closing letters/commercial-alert-response-letter/commercialalertletter.pdf (last visited on Aug. 11, 2016).

115. Letter from Mary K. Engle, Associate Director for Advertising Practices (FTC 2013 Search Engine Letter), June 24, 2013, available at http:/www.ftc.gov/sites/default/files/ attachments/press-releases/ftc-consumer-protection-staff-updates-agencys-guidancesearch-engine-industryon-need-distinguish/130625searchenginegeneralletter.pdf (last visited on Aug. 11, 2016).

116. Id.

117. Songsong Lu, Baidu's Ranking Rules and Its Algorithm [百度排名规则及算法总结] <available only in Chinese>, Sept. 8, 2015, available at http://mt.sohu.com/20150908/n420631499. shtml (last visited on Aug. 11, 2016). 
118. See Baidu's Objectivity Compromised by Profit Model: Investigation, China DaIly, June 10, 2016, available at http://www.chinadaily.com.cn/business/2016-05/10/content_25184744. htm (last visited on Aug. 11, 2016).

119. D. Balto, The FTC Should Update Search Engine Transparency Guidelines, Huffington Post, June 21, 2012, available at http://www.huffingtonpost.com/david-balto/ftc-searchengines_b_1608901.html (last visited on Aug. 11, 2016).

120. S. Waller, Access and Information Remedies in High Tech Antitrust, 8 J. Competition L. \& ECONOMICS 575 (2011).

121. Id.

122. Id.

123. P. Alexiadis \& E. Sependa, Structural Remedies under European Union Antitrust Rules, 2 COMPETITION L. J. 12-31 (2013), available at http://www.gibsondunn.com/publications/ Documents/AlexiadisSependa-StructuralRemedies.pdf (last visited on Aug. 11, 2016).

124. Id.

125. E.g., NDRC decision on Qualcomm abuse of dominance.

126. Indeed, in the Commission's Merger Remedies Notice (OJ C 267/1, 22 October 2008), access remedies are described as "other structural remedies" in Section 17, but bracketed with behavioral remedies as "other remedies" that are distinct from divestiture remedies specified in Section III.3.

127. Supra note 89.

128. Kopel, supra note 5.

129. Id. 
